\title{
WASTE MINIMIZATION OPPORTUNITIES AT THE U.S. URANIUM MILL TAILINGS REMEDIAL ACTION (UMTRA) PROJECT \\ RIFLE, COLORADO, SITE
}

\author{
George L. Hartmann \\ Geraghty \& Miller \\ 5301 Central Ave. NE, Suite 1700 \\ Albuquerque, New Mexico 87108 \\ Sharon Arp \\ U.S. Department of Energy \\ 5301 Central Ave. NE, Suite 1700 \\ Albuquerque, New Mexico 87108 \\ Hugh Hempill \\ Morrison Knudsen-Environmental Services \\ A Division of MK-F \\ 180 Howard Street \\ San Francisco, California 94105
}

\begin{abstract}
Waste minimization is not limited to industrial production activities. It can be applied to the remediation of contaminated sites by reducing the volume of waste generated or by recycling waste material. At two uranium mill sites in Rifle, Colorado, the U.S. Department of Energy (DOE) Uranium Mill Tailings Remedial Action (UMTRA) Project is removing uranium mill tailings and contaminated subgrade soils. This remediation activity will result in the production of groundwater contaminated with uranium, heavy metals, ammonia, sulfates, and total dissolved solids (TDS). The initial remediation plan called for a wastewater treatment plant for removal of the uranium, heavy metals, and ammonia, with disposal of the treated water, which still includes the sulfates and TDSs, to the Colorado River.
\end{abstract}

The National Pollutant Discharge Elimination (NPDES) permit (Colorado Discharge Permit No. C0-0042552) issued by the Colorado Department of Health for the two Rifle sites contained more restrictive discharge limits than originally anticipated. During the detailed review of alternate treatment systems to meet these more restrictive limits, the proposed construction procedures were reviewed emphasizing the methods to minimize groundwater production to reduce the size of the water treatment facility, or to eliminate it entirely. It was determined that with changes to the excavation procedures and use of the contaminated groundwater for use in dust suppression at the disposal site, discharge to the river could be eliminated completely. These changes, coupled with revision of the construction work schedule, will eliminate the need to treat and discharge the water produced during site dewatering activities. Dewatering volumes are now projected at 24 million gallons, a reduction of $\mathbf{7 7}$ percent from the original estimate, and the need for a $\$ 3$ to 5 million wastewater plant has been eliminated.

DISTRIBUTION OF THIS DOCUMENT IS UNLIMITED WW

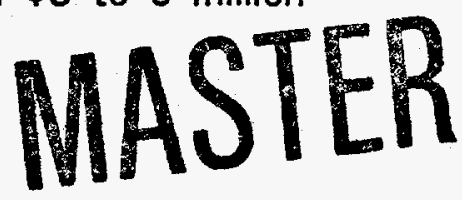




\section{INTRODUCTION}

The Uranium Mill Tailings Radiation Control Act (UMTRCA) of 1978, Public Law 95-604, authorized the U.S. Department of Energy (DOE) to perform remedial action to reduce the potential public health impacts from the residual radioactivity at 24 sites across the country including the two processing sites at Rifle, Colorado. This paper describes the actions taken to develop a plan to minimize waste treatment and disposal of contaminated water produced during the remedial actions at the Rifle site.

Generally, waste minimization is associated with industrial activities as opposed to the remediation of contaminated facilities. However, the basic principles of waste minimization, which include reducing the volume of wastes produced, recycling or reusing waste materials, concentrating the wastes to reduce waste volume, and segregating materials to minimize contaminating larger volumes of material, are all used at the Rifle sites in the remediation of the tailings.

\section{BACKGROUND}

The two UMTRA Project sites near Rifle, Colorado, are known as New Rifle and Old Rifle. Rifle, Colorado, is approximately 81 kilometers $(\mathrm{km})(50$ miles) east of Grand Junction, Colorado, and is located on the Colorado River (see Figure 1). The Old Rifle site is approximately $0.5 \mathrm{~km}(0.3$ mile) east of the city of Rifle while the New Rifle site is $3.2 \mathrm{~km}(2$ miles) west, or downstream of the city [DOE, 1992a]. The New Rifle tailings site covers 57.5 hectares (142 acres), while the Old Rifle site covers 8.9 hectares (22 acres) (see Figure 2).

The site areas include a mill area, tailings piles, and adjacent contaminated windblown areas. This total volume of contaminated material, including tailings and contaminated soils, is 505,000 cubic meters $\left(\mathrm{m}^{3}\right)\left(661,000\right.$ cubic yards $\left.\left[\mathrm{yd}^{3}\right]\right)$ at Old Rifle and $2,700,000 \mathrm{~m}^{3}$ $\left(3,500,000 \mathrm{yd}^{3}\right)$ at New Rifle [DOE, 1992a]. Figures 3 and 4 show the sites in more detail. The Old Rifle site operated intermittently between 1924 and 1958 processing vanadium initially and later uranium. The New Rifle site processed uranium between 1958 and 1973. From 1973 until 1984, when it was closed, the mill processed vanadium. As can be seen from Figures 2, 3 and 4 the sites lie adjacent to the Colorado River and the tailings piles are located on the existing river alluvium (silt, sand, and gravel) material on the valley floor. Groundwater at the two sites ranges from $0.6 \mathrm{~m}$ ( 2 feet) to $3 \mathrm{~m}$ (10 feet) below ground surface depending on the flow in the Colorado River.

Phase I of the UMTRA Project remediation program is the removal or stabilization in place, of the tailings and associated contaminated materials and soils under the tailings. Due to leaching from the tailings and associated water storage ponds, contaminants have been leached from the tailings into the underlying soils and groundwater at the two Rifle sites. Groundwater contaminants that exceed Environmental Protection Agency (EPA) proposed groundwater standards include arsenic, cadmium, chromium, molybdenum, nitrate, selenium, uranium, and gross alpha activity. Proposed EPA groundwater protection standards applicable to the Rifle UMTRA Project sites are shown in Table 1. Additional nonhazardous contaminants found in the New Rifle site groundwater were TDS, up to 24,000 milligrams/liter (mg/L), ammonia up to $800 \mathrm{mg} / \mathrm{L}$ and sulfates up to $20,000 \mathrm{mg} / \mathrm{L}$. At the Old Rifle site these contaminants were two orders of magnitude lower [DOE, 1992a]. Phase II of the UMTRA Project will address the remediation of the contaminated groundwater at the mill tailings sites. 


\section{DISCLAIMER}

Portions of this document may be illegible in electronic image products. Images are produced from the best available original document. 


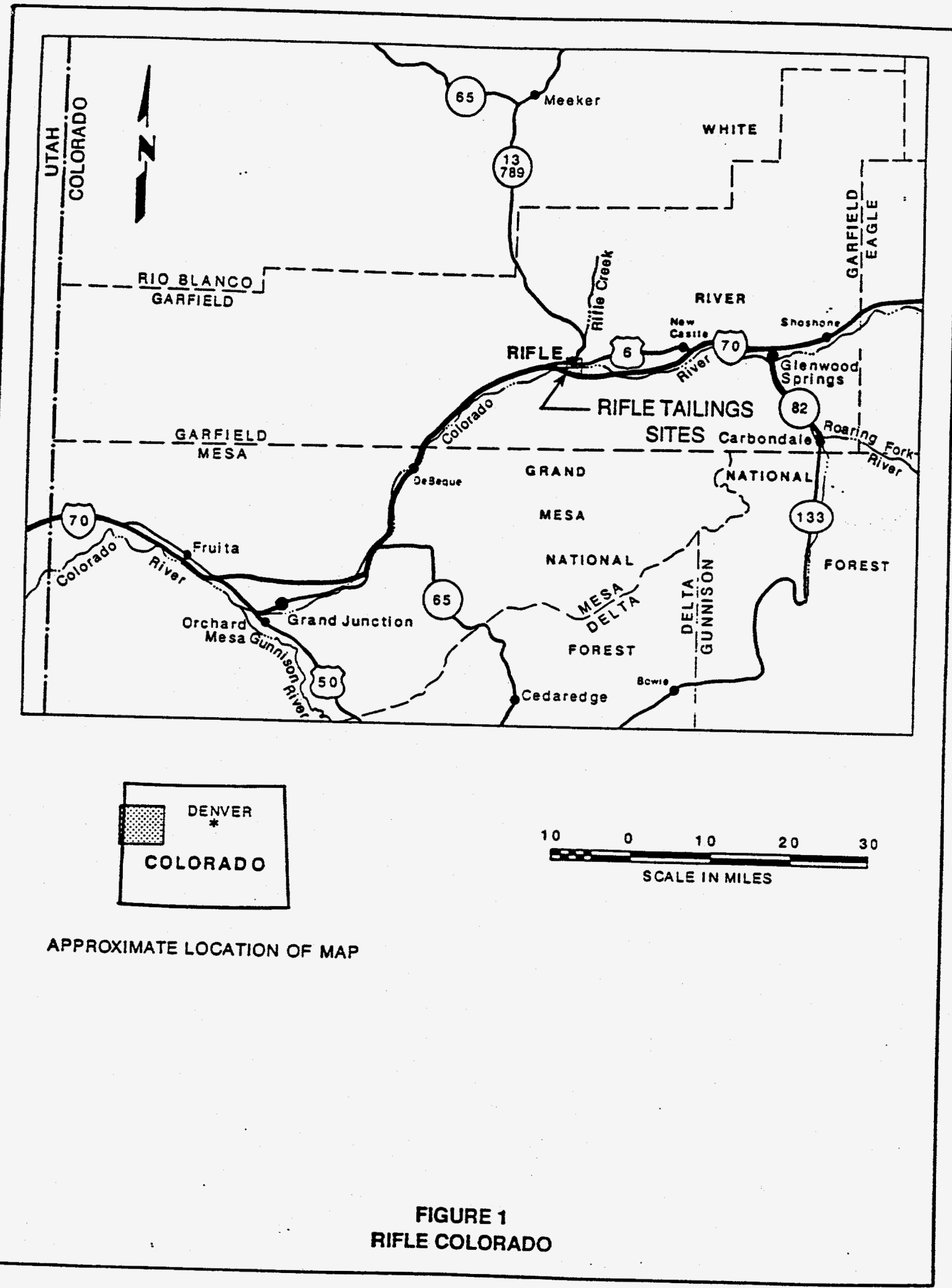




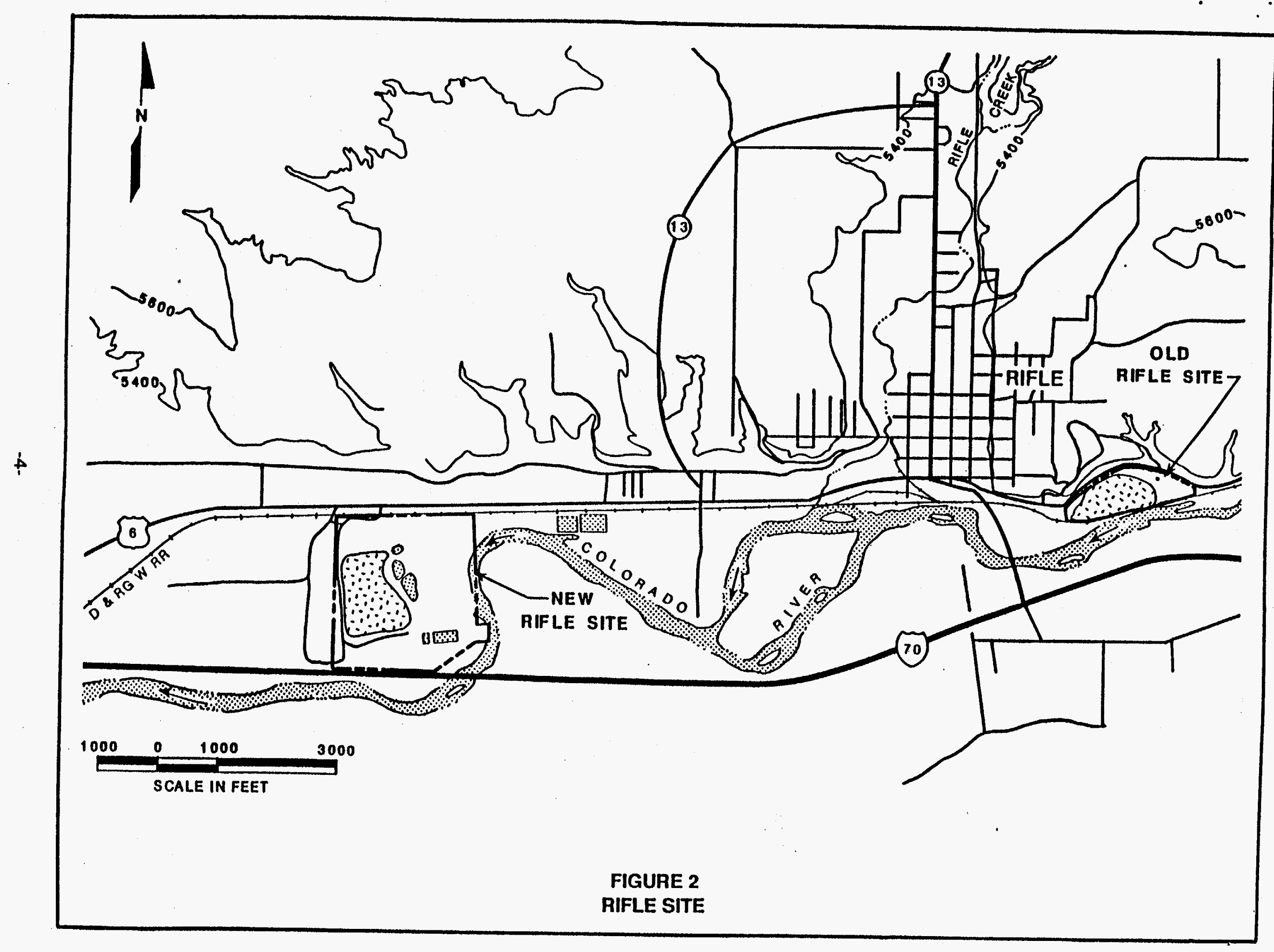




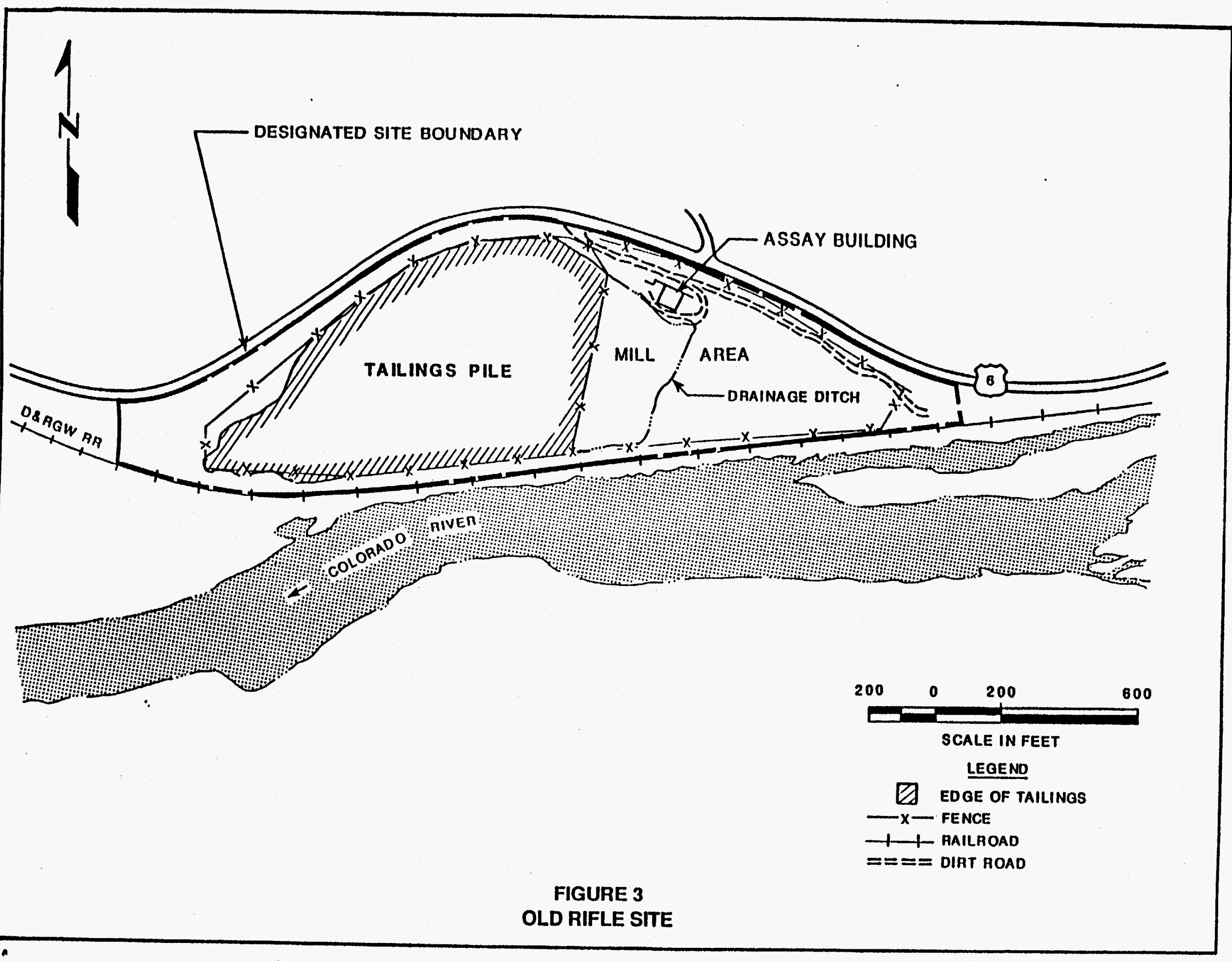




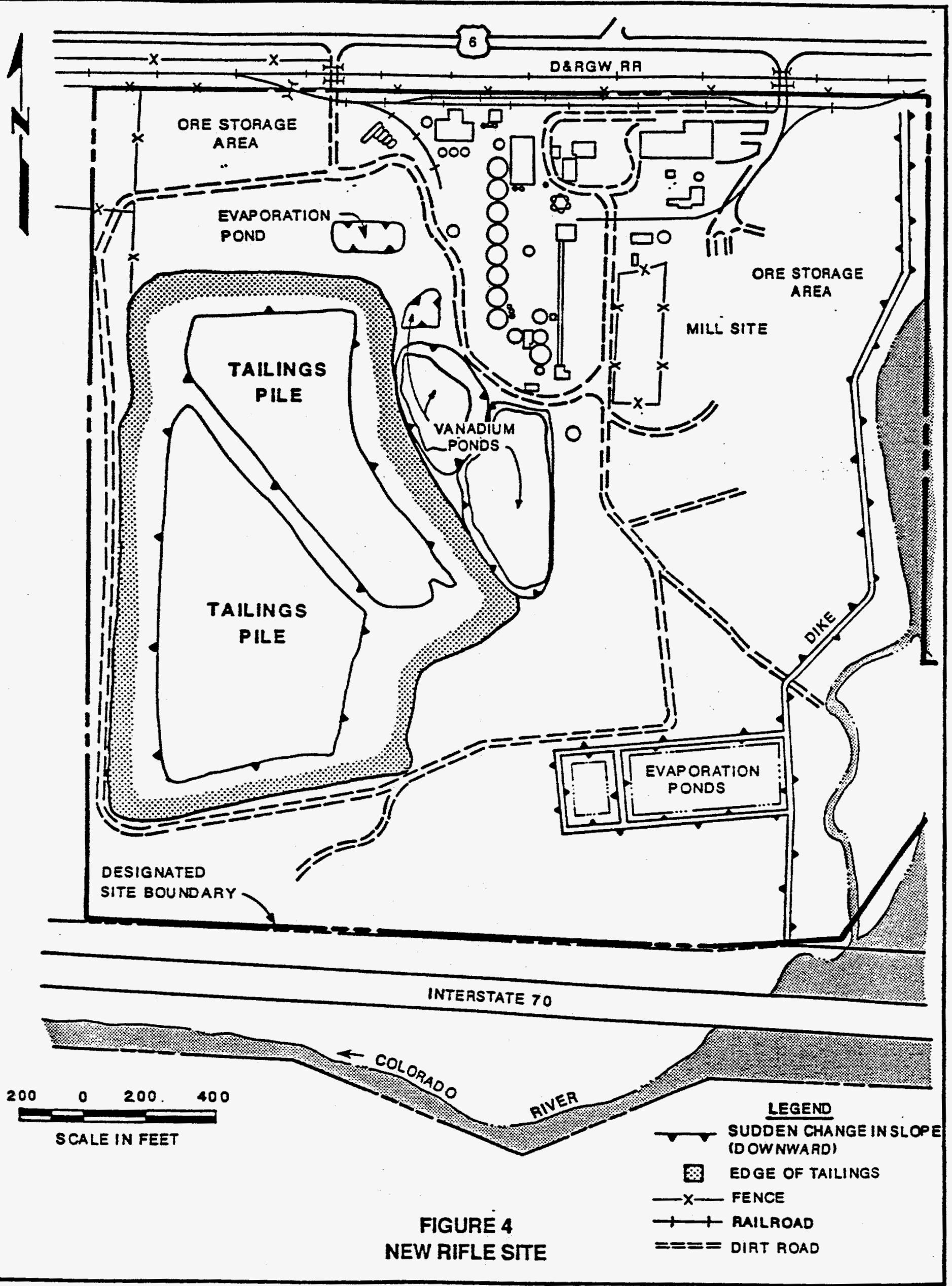


Table 1. Proposed EPA Groundwater Protection Standards Applicable to the Rifle UMTRA Project Sites

\begin{tabular}{|c|c|}
\hline Constituent & Maximum Concentration Limit (MCL) \\
\hline Inorganic Chemical' & mg/L \\
\hline $\begin{array}{l}\text { Arsenic } \\
\text { Barium } \\
\text { Cadmium } \\
\text { Chromium } \\
\text { Lead } \\
\text { Mercury } \\
\text { Molybdenum } \\
\left.\text { Nitrate (as } \mathrm{NO}_{3}\right)^{b} \\
\text { Selenium } \\
\text { Silver }\end{array}$ & $\begin{array}{l}0.05 \\
1.00 \\
0.01 \\
0.05 \\
0.05 \\
0.002 \\
0.1 \\
44 \\
0.01 \\
0.05\end{array}$ \\
\hline Radionuclides $^{\mathbf{a}}$ & $\mathrm{pCi} / \mathrm{L}$ \\
\hline $\begin{array}{l}\text { Ra-226 and } R a-228 \\
U-234 \text { and } U-238 \\
\text { Gross Alpha (excluding uranium and radon) }\end{array}$ & $\begin{array}{l}5 \\
30(0.44 / \mathrm{mg} / \mathrm{L}) \\
15\end{array}$ \\
\hline Organic Chemical $^{c}$ & $\mathrm{mg} / \mathrm{L}$ \\
\hline $\begin{array}{l}\text { Methoxychlor } \\
\text { Endrin } \\
\text { Lindane } \\
\text { Toxaphene } \\
\text { 2,4-D } \\
2,4,5-T P \text { (Silvex }\end{array}$ & $\begin{array}{l}0.0002 \\
0.004 \\
0.10 \\
0.005 \\
0.10 \\
0.01\end{array}$ \\
\hline
\end{tabular}

aProposed EPA Groundwater Protection Standards-UMTRA, 52 FR 36,000

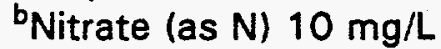

'See Appendix VIII, 40 CFR Part 261 for complete list of hazardous organic constituents.

Under the UMTRA Project the tailings piles can be stabilized in place or they can be removed and placed in a disposal cell. EPA established standards for the performance of the remediated sites, stabilized piles, and disposal cells. The UMTRCA regulations call for a longevity standard of 1000 years for the remediated sites whenever reasonably possible, but in any case a minimum performance period of 200 years must be achieved, 40 CFR 192.02(a) [DOE, 1989]. Because of the location of the two Rifle piles adjacent to the Colorado River and the potential for periodic flooding of the pile, an offsite disposal cell was selected for placement of the material.

Disposal cell construction began in 1992 at Estes Gulch, which is located approximately 10 $\mathrm{km}$ ( 6 miles) north of the city of Rifle. Removal of the tailings piles will begin in 1993 and removal of the contaminated alluvial material and windblown material are scheduled for 1994, with completion of all work in 1996. 
Surface remediation standards in 40 CFR $192.12(a)(1)$ and (2) require the removal of soil tailings and contaminated soils as follows: The concentration of radium-226 in land averaged over any area of 100 square meters shall not exceed the background by $5 \mathrm{pCi} / \mathrm{g}$, averaged over the first $15 \mathrm{~cm}$ of soil below the surface, and $15 \mathrm{pCi} / \mathrm{g}$, averaged over $15-\mathrm{cm}$-thick layers of soil more than $15 \mathrm{~cm}$ below the surface. Contaminated soils exceeding this activity level are found below the water table in different portions of the sites. To excavate these materials it is necessary to lower the water table below this contaminant elevation. The initial construction plan provided for dewatering these areas, treating the water and discharging the treated water into the Colorado River [DOE, 1992a].

\section{WATER TREATMENT AND WASTE MINIMIZATION}

The original construction plan required capture of storm water from the site during construction. In addition, groundwater removed during the dewatering activities would be contained with the storm water in lined holding ponds at the two sites before treatment and discharge to the Colorado River. Plans called for the construction of a $3460 \mathrm{~m}^{3}(2.8$ acre-ft) retention basin at Old Rifle and a $11,100 \mathrm{~m}^{3}(9$ acre-ft) basin at New Rifle. Stabilized contaminants removed from the water would be hauled to the Estes Gulch disposal cell for burial with the tailings.

A Colorado Discharge Permit System (CDPS) permit application was submitted to the state of Colorado for treatment plants at both the Rifle sites in 1989. The permit application requested permits for $1360 \mathrm{~m}^{3} /$ day $(250 \mathrm{gpm})$ discharge at both of the Rifle plants. This was a very conservative design and was based in part on use of an existing water treatment plant that would be relocated from a previously remediated UMTRA site. Removals were based on uranium mine processing effluent standards contained in 40 CFR 440.32 and 33 . Included in these standards were ammonia nitrogen limits of $200 \mathrm{mg} / \mathrm{L}$. No limits were set for TDS. These standards were to be met with a chemical precipitation plant followed by an ammonia air stripping unit.

Table 2 lists the expected volume of groundwater and the water quality for each of the sites.

Table 2. Expected Volume of Groundwater and Water Quality

\begin{tabular}{lll}
\hline & Old Rifle & New Rifle \\
\cline { 2 - 3 } Groundwater volume & $2.83 \times 10^{5} \mathrm{~m}^{3}$ & $1.12 \times 10^{5} \mathrm{~m}^{3}$ \\
& $\left(74.7 \times 10^{6} \mathrm{gal}\right)$ & $\left(31.7 \times 10^{6} \mathrm{gal}\right)$ \\
$\mathrm{NH}_{4}-\mathrm{N}$ & $800 \mathrm{mg} / \mathrm{L}$ & 0.5 \\
TDS & $706 \mathrm{mg} / \mathrm{L}$ & 9206 \\
\hline
\end{tabular}

a Wastewater Treatment at the Rifle Colorado UMTRA Site, Draft Report, MK-F and MK-E, February 1992 
The concentrations of both TDS and ammonia had dropped at both sites between 1987 when the initial wastewater design was proposed and 1992 values due to natural flushing of the alluvial material.

During the period the permit application was being processed, the EPA Region VIII Office and the state of Colorado implemented the "EPA Region VIII NPDES Whole Effluent Toxics Control Program" (EPA/600/4-89/001). This program required a two-species acute and chronic testing method for determining the acceptability of point source discharges. Based on previous whole effluent toxicity (WET) testing on other effluents it is expected that a $20 \mathrm{mg} / \mathrm{L}$ limit for ammonia would now be required to pass the WET testing requirements and TDS would probably have to be reduced to less than $1500 \mathrm{mg} / \mathrm{L}$. Both the draft permit (Colorado Discharge Permit No. CO-0042552) issued in November 1991 and the final permit issued in January 1992, contained this requirement [CDH, 1992] [EPA, 1989]. The permit also limited the total quantity of TDS that could be discharged from each of the Rifle water treatment plants to 0.9 tonnes ( 1.0 ton) per day based on the Colorado River Salinity Standards [The Colorado Water Quality Control Commission, 1989]. Based on the combined flow from the two sites, a TDS loading to the river, without TDS removal, would amount to 11 tons/day (10 tonnes/day), based on the planned 120-day operating period. Therefore, the original water treatment plant concept would not be acceptable at the Rifle sites. Alternative treatment methods were evaluated to meet these new effluent requirements and changes in construction procedures were investigated that would reduce the quantity of groundwater and the size of the treatment facilities.

Eight alternative treatment technologies were considered for meeting the TDS limits of 0.9 tonnes $(1.0 \mathrm{ton})$ per day and the ammonia limit of $20 \mathrm{mg} / \mathrm{L}$. Technologies examined are as follows:

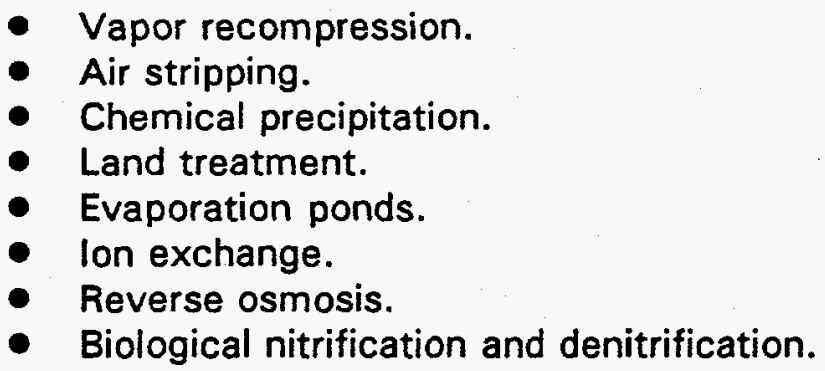

No single technology could meet all the permit requirements for metals removal, ammonia removal, and TDS removal except for vapor recompression and evaporation ponds. Evaporation ponds were not suitable due to the large acreage required. A vapor recompression concentrator (an evaporator) with a filter press for solids dewatering was recommended as the best process for meeting the effluent limits. Dewatered solids would be hauled to the Estes Gulch disposal cell. The estimated cost of this process was estimated to be approximately $\$ 4,000,000$. Alternative treatment methods were found to range alone up to $\$ 11,200,000$ for an ion exchange plant to remove all contaminants [DOE, 1992b].

A method of water disposal that had been used at other UMTRA sites involved using the treated storm water and groundwater for dust control at the tailings sites during construction. At Rifle this type of use had also been considered; however, detailed dust control needs had 
not been studied since the original wastewater treatment system was predicated on using an existing DOE water treatment plant.

Untreated groundwater could be used for dust control at Rifle provided it was used on those areas where the material would later be removed and hauled to the disposal cell. A review of dust control water use during the previous summers revealed that up to $1514 \mathrm{~m}^{3} / \mathrm{d}$ $\langle 400,000 \mathrm{gpd})$ of water was being used in this manner at the New Rifle site [DOE, 1992c]. This quantity was based on water use on the existing vegetated and windblown areas. With this large potential reuse of the groundwater, a more detailed water balance was undertaken to determine what water quantity could be used for dust control on the site during the 4-month period when the sites were undergoing dewatering activities. The study was based on an application rate 0.028 to $0.55 \mathrm{~cm} /$ day $(0.07$ to 0.14 inches/day) for the bare soil windblown areas [DOE, 1992c]. Based on this application rate and an available windblown dust control area available of 52.6 to 38.5 hectare (130 to 95 acres) at the New Rifle site, a water balance for the site was conducted. The water volumes used for this study included both surface storm water volumes and water produced during the alluvial material excavation. Before this study was conducted, revisions to the construction schedule and construction procedures were revised to minimize groundwater production, and maximize the availability of windblown area for use in receiving the groundwater.

Alternative construction techniques were evaluated that could reduce the quantity of groundwater that had to be removed. These alternatives are as follows:

- Reduction of the construction period where dewatering would be required from two construction seasons to one construction season. The original schedule entailed removing contaminated alluvial material over two separate years. Revisions to the construction schedule provided for limiting the dewatering period to one construction season, with removal of the contaminated windblown areas after the contaminated alluvial material under the tailings piles had been removed.

- Excavation of the sites was originally assumed to be done as large open pits. Studies determined that excavation of the material could be done in strips, approximately $30.7 \mathrm{~m}(100 \mathrm{ft})$ wide and immediately backfilled as excavation was being done. This procedure was calculated to reduce dewatering volumes by $51,500 \mathrm{~m}^{3}\left(13.6 \times 10^{6}\right.$ gallons) at New Rifle and $1893 \mathrm{~m}^{3} 10.5$ million gallons) at Old Rifle.

- Installation of slurry walls at the two sites were studied. Installation of slurry walls at the two sites was calculated to reduce dewatering volumes by $246,000 \mathrm{~m}^{3}\left(65.1 \times 10^{6}\right.$ gallons $)$ at the Old Rifle site and $51,500 \mathrm{~m}^{3}(13.6 \times$ $10^{6}$ gallons) at the New Rifle site.

Together, use of the slurry walls and the slot excavation procedures were calculated to reduce the dewatering volume to a total of $90,800 \mathrm{~m}^{3}\left(24 \times 10^{6}\right.$ gallons $)$ from the originally estimated $402,000 \mathrm{~m}^{3}\left(106.4 \times 10^{6}\right.$ gallons), a reduction of 78.4 percent [DOE, 1992c]. These reduced dewatering volume estimates indicated that the alternative of using this water for dust control was a viable option.

Separately, a WET test was conducted on samples of the Old Rifle site groundwater in late 1992 [CDH, 1992]. The groundwater passed the test as well as meeting all other Old Rifle site NPDES permit discharge requirements. 
With this analysis a more detailed evaluation of dust control water needs was conducted as described earlier. As a result of these studies the following water treatment/water disposal methods were adopted.

- An additional 16,000 $\mathrm{m}^{3}$ (13.0 acre-foot) storage pond would be constructed at New Rifle for the water removed during dewater activities. The existing $11,100 \mathrm{~m}^{3}$ (9 acre-foot) storage pond would just receive storm water runoff. It is anticipated that this storm water will meet the permit discharge standards without treatment since it will not be in contact with heavily contaminated soils, tailing material, or the contaminated groundwater. This water will be used for dust control if possible rather than being discharged to the river.

- The Old Rifle storm water retention basin was large enough for storage of storm water runoff and water produced by the dewatering activities with the use of the slot excavation and slurry walls. This water will be used for dust control water at the Old Rifle site, trucked to New Rifle for dust control or discharged to the Colorado River if it meets the CDPS effluent discharge limits and it is not used for dust control.

The changes in construction procedures and utilization of the water for on-site dust control are summarized below.

- Reduced TDS discharge to the Colorado River from the New Rifle site 1,105 tonnes (1216 tons).

- Eliminated the use of $29,600 \mathrm{~m}^{3}$ ( 24 million gallons) of Colorado River water for dust control.

- Eliminated the installation of a vapor recompression facility at a cost of approximately $\$ 4,000,000$ at the site.

Probably the best lesson learned from this project was the fact that changing regulations can be the driving force to implement better environmental solutions to remediation activities. Without the tighter discharge requirements, the elimination of the discharge to the Colorado River would probably not have been achieved.

A final note is that these facility changes would not have been possible without the close cooperation of the DOE, the remediation contractor Morrison Knudsen-Ferguson, their consultants Morrison Knudsen-Environmental Services, the Technical Assistance Contractor Jacobs Engineering Group inc., and the state of Colorado UMTRA representatives.

\section{REFERENCES}

$\mathrm{CDH}$ (Colorado Department of Health), April 1992. "The Regulations for the State Discharge Permit System," 5CCR1002-2, Section 6.9.7, Denver, Colorado.

Colorado Water Quality Control Commission, 1989. "Regulations for Implementation of the Colorado River Salinity Standards Through the NPDES Program," 5 CCR 1002-11, Regulation Section 3.10.0; Colorado River Salinity Standards List.

DOE (U.S. Department of Energy), 1992a. Remedial Action Plan and Site Desian for Stabilization of the Inactive Uranium Mill Tailings Sites at Rifle, Colorado, prepared 
by the U.S. Department of Energy, UMTRA Project Office, Albuquerque Operations Office, Albuquerque, New Mexico.

DOE (U.S. Department of Energy), 1992c. UMTRA Project - Rifle Wastewater Management Study, Rifle Processing Sites, Revision 1, prepared by MK-Ferguson, UMTRA Project Office, Albuquerque, New Mexico, and MK-Environmental Services, UMTRA Project Office, San Francisco, California, for the U.S. Department of Energy, UMTRA Project Office, Albuquerque Operations Office, Albuquerque, New Mexico.

DOE (U.S. Department of Energy), 1992b. Wastewater Treatment at the Rifle, Colorado, UMTRA Site, Draft, prepared by MK-Ferguson, UMTRA Project Office, Albuquerque, New Mexico, and MK-Environmental Services, UMTRA Project Office, San Francisco, California, for the U.S. Department of Energy, UMTRA Project Office, Albuquerque Operations Office, Albuquerque, New Mexico.

DOE (U.S. Department of Energy), 1989. Technical Approach Document, UMTRA-DOE/AL050425.0002 , prepared by the U.S. Department of Energy, UMTRA Project Office, Albuquerque Operations Office, Albuquerque, New Mexico.

EPA, March 1989. "Short-Term Methods for Estimating the Chronic Toxicity of Effluents and Receiving Waters to Freshwater Organisms, EPA/600/4-89/001, Washington, D.C.

\section{DISCLAIMER}

This report was prepared as an account of work sponsored by an agency of the United States Government. Neither the United States Government nor any agency thereof, nor any of their employees, makes any warranty, express or implied, or assumes any legal liability or responsibility for the accuracy, completeness, or usefulness of any information, apparatus, product, or process disclosed, or represents that its use would not infringe privately owned rights. Reference herein to any specific commercial product, process, or service by trade name, trademark, manufacturer, or otherwise does not necessarily constitute or imply its endorsement, recommendation, or favoring by the United States Government or any agency thereof. The views and opinions of authors expressed herein do not necessarily state or reflect those of the United States Government or any agency thereof. 